Jurnal Pendidikan Sosial Keberagaman

Print-ISSN 2355-4622 Online-ISSN 2622-9021

Vol. 8, No. 1, Juli 2021, halaman 10-29

https://juridiksiam.unram.ac.id/index.php/juridiksiam

\title{
HABITUASI NILAI-NILAI KARAKTER SEBAGAI PERILAKU ANTI KORUPSI PADA MASYARAKAT KAJANG
}

\author{
Bagdawansyah Alqadri', Edy Kurniawansyah², Ahmad Fauzan ${ }^{3}$ \\ Universitas Mataram ${ }^{\mathbf{1 2 3}}$ \\ bagda_alqadri@unram.ac.id
}

\begin{abstract}
Abstrak
Penelitian ini bertujuan (i) Untuk mengetahui nilai-nilai karakter mana saja yang ada pada komunitas masyarakat Kajang yang berkaitan dengan perilaku anti korupsi; (ii) Untuk mengetahui kesesuaian antara nilainilai karakter komunitas masyarakat Kajang dengan Undang-Undang Anti Korupsi; (iii) Untuk mengetahui bagaimana nilai-nilai karakter komunitas Kajang membentuk (mengkonstruksi) perilaku anti korupsi warga masyarakat. Penelitian ini termasuk dalam kategori deskriptif kualitatif yang bertujuan untuk mendeskripsikan atau menjelaskan secara mendalam habituasi nilai-nilai karakter yang berupa kearifan lokal (local wisdom) pada masyarakat kajang, dalam hal membentuk perilaku anti korupsi. Penelitian ini dilakukan pada masyarakat Kajang, tepatnya Kecamatan Kajang Kabupaten Bulukumba. Daerah ini dipilih sebagai basis penelitian mengingat sebagian besar komunitas Kajang mendiami beberapa desa yang tersebar di kecamatan ini. Pemilihan desa sebagai lokasi penelitian dilakukan dengan pertimbangan bahwa beberapa desa yang dipilih diharapkan dapat mewakili komunitas Kajang dalam (masyarakat yang relatif belum bersentuhan dengan dunia luar), dan komunitas Kajang luar (relatif telah bersentuhan dengan dunia luar). Hasil penelitian ini menunjukkan bahwa (i) Nilai karakter masyarakat adat Kajang berkaitan dengan Perilaku Anti Korupsi dapat dideskripsikan bahwa Pasang merupakan suatu tatanan yang majemuk diwariskan oleh leluhur dari masyarakat adat Kajang untuk dijadikan sebagai tuntunan dalam menjalankan kehidupan di dunia yang tidak terlepas dari prinsip hidup kamase-asea; (ii) Pemberlakuan Undang-Undang Anti Korupsi oleh pemerintah juga diterapkan oleh komunitas adat Ammatoa. Meskipun, ada perbedaan karena aturan-aturan yang diberlakukan oleh komunitas adat Ammatoa tidak tertulis, melainkan berupa Pasang yang sangat dipatuhi oleh masyarakat adat Kajang; (iii) Proses internalisasi fakta sosial yang terjadi melalui prinsip kamase-asea sebagai nilai yang di pegang teguh oleh masyarakat adat Kajang dengan Perilaku Anti Korupsi sebagai fakta hukum yang terjadi melalui jalur Lingkungan Keluarga serta Lingkungan Masyarakat. Selain itu, sanksi yang tegas dan berat diperlukan sehingga masyarakat tidak berani untuk melakukan pelanggaran. Hal inilah yang dapat membentuk suatu sikap Perilaku Anti Korupsi dalam masyarakat secara umum.
\end{abstract}

Kata kunci : Habituasi; Kajang;Karakter;Korupsi

\begin{abstract}
This research aims (i) to know the character values of Kajang community in Anti-Corruption behavior; (ii) to know the correlation between character values of Kajang community with corruption statute; (iii) to know how the Kajang community character value to establish Anti-Corruption behavior in the society. This research is qualitative description aims to describe or explain about the character values of habituation by the local wisdom in Kajang community to establish Anti-Corruption behavior. This research implemented in Kajang Community on Kajang sub district, Bulukumba district. This area chosen in the writer research because almost the Kajang community lives in the some village around this sub district. Selection of village a research location was did with consideration that some of village which is chosen hopeful can represent the Kajang community inside (the society whose doesn't touch with the outside world relatively) and Kajang community from the outside ( have touched with outside world relatively). The result of this research showed that (i) character values of Kajang community's tradition related to Anti-Corruption behavior can to described that Pasang is a social order of Kajang community as a guidance to operate our life in the world that related to principle of life,Kamasea-asea. (ii) Put into effect Anti-Corruption statute by the government also applied by Ammatoa community. Although, there is different because the regulation that used by Ammatoa community was not be written. But, Pasang is very obedient for Kajang community. (iii) Internalization process of social fact that happened through Kamaseaasea principle as a hard value of Kajang community with Anti-Corruption behavior as law fact that happened through family circle and society circle stripe. The other hand, district punishment is needed. So that, the society has not a brave to makes infraction. It can establish Anti-Corruption behavior in society generally.
\end{abstract}




\section{Jurnal Pendidikan Sosial Keberagaman}

Print-ISSN 2355-4622 Online-ISSN 2622-9021

Vol. 8, No. 1, Juli 2021, halaman 10-29

https://juridiksiam.unram.ac.id/index.php/juridiksiam

\section{A. Latar Belakang}

Dari hasil survei Transparency International pada akhir 2011, Indonesia menempati peringkat 100 dari 183 negara di dunia yang ter-korup (Kompas.com). Hal ini menunjukkan bahwa betapa buruknya moralitas masyarakat di Indonesia. Di sisi lain, Indonesia sangat terkenal di mata dunia dengan kultur yang ramah dan sangat santun, namun perilaku korupsi masyarakat Indonesia sangat tinggi. Selain itu, Harian Seputar Indonesia (13 Maret 2007) menurunkan berita dengan judul: "4000 Dewan Tersangka Korupsi”. Dalam tulisan ini disebutkan bahwa wakil rakyat yang terjerat korupsi tersebar dari Dewan Perwakilan Rakyat (DPR), Dewan Perwakilan Rakyat Daerah (DPRD) Tingkat I dan II. Tindak korupsi yang merajalela merupakan pencerminan buruknya karakter mayoritas penyelenggara Negara di Indonesia. Dengan demikian, masih banyak hal dalam negara ini yang harus dibenahi. Walaupun kita ketahui bahwa tidak semua organ yang ada dalam pemerintahan itu buruk, yang menjalankan sikap-sikap kurang bermoral oleh para penentu kebijakan yang perlu diberantas. Disinilah peran pendidikan karekter yang seharusnya terpatri dalam diri manusia sebelum melakukan kejahatan moral.

Dalam upaya mencegah semakin maraknya perilaku korupsi terutama di kalangan pejabat negara, berbagai model dan strategi harus dilakukan. Salah satu upaya yang dinilai dapat melakukan pencegahan perilaku korupsi, adalah mengambil nilai-nilai kearifan lokal (local wisdom) yang berupa nilai-nilai sosial yang diyakini kebenarannya oleh masyarakat yang masih memegang kuat adat. Oleh karena itu diperlukan langkah kongkrit berupa strategi untuk mendorong nilai-nilai kearifan lokal yang masih tetap terpelihara di masyarakat atau komunitas tertentu adalah langkah yang sangat tepat. Salah satu komunitas yang di pandang masih memiliki nilai sosial dan tetap terpelihara hingga kini adalah masyarakat Kajang. Pada masyarakat kajang disamping memiliki sejumlah nilai sosial yang terkait erat dengan penolakan perilaku korupsi, komunitas ini dipandang masih unik sekaligus memiliki karakter yang kuat, berupa komunitas adat Ammatoa atau Adat Kajang.

Dengan demikian, penulis menganggap perlunya studi yang mengaitkan antara nilainilai karakter dengan perilaku korupsi, dengan melihat suku dan budaya yang sangat menjunjung tinggi nilai-nilai luhur terkhusus lagi pada suku Adat Kajang, sehingga dalam studi ini dapat diperoleh hasil untuk menguatkan nilai-nilai karakter baik itu dalam dunia peendidikan maupun masyarakat secara umum serta dapat menekan bahkan menghapuskan budaya korupsi di negara ini. 


\section{Jurnal Pendidikan Sosial Keberagaman}

Print-ISSN 2355-4622 Online-ISSN 2622-9021

Vol. 8, No. 1, Juli 2021, halaman 10-29

https://juridiksiam.unram.ac.id/index.php/juridiksiam

\section{B. Rumusan Masalah}

Berdasarkan latar belakang di atas maka beberapa hal yang menjadi permasalahan dalam penelitian ini adalah sebagai berikut:

1. Nilai-nilai karakter (local wisdom) mana saja yang ada pada komunitas masyarakat Kajang yang berkaitan dengan perilaku anti korupsi ?

2. Bagaimana kesesuaian antara nilai-nilai karakter komunitas masyarakat Kajang dengan Undang-Undang Anti Korupsi ?

3. Bagaimana nilai-nilai karakter komunitas Kajang membentuk (mengkonstruksi) perilaku anti korupsi warga masyarakat?

\section{Tujuan Penelitian}

Tujuan yang ingin di capai oleh peneliti dalam penelitian ini adalah sebagai berikut :

1. Untuk mengetahui nilai-nilai karakter (local wisdom) mana saja yang ada pada komunitas masyarakat Kajang yang berkaitan dengan perilaku anti korupsi ;

2. Untuk mengetahui kesesuaian antara nilai-nilai karakter komunitas masyarakat Kajang dengan Undang-Undang Anti Korupsi ;

3. Untuk mengetahui bagaimana nilai-nilai karakter komunitas Kajang membentuk (mengkonstruksi) perilaku anti korupsi warga masyarakat;

4. Penelitian ini diharapkan mampu memberi masukan bagi pemerintah dalam menentukan kebijakan dalam permasalahan korupsi terutama kepada lembaga negara yang khusus menangani tindak pidana khusus korupsi yaitu Komisi Pemberntasan Korupsi (KPK).

\section{Tinjauan Teoritis}

\section{A. Habituasi Nilai-Nilai Masyarakat}

Habituasi adalah suatu kondisi yang terjadi dimana kita sudah terbiasa dengan suatu stimulus sehingga lama-lama kita makin kurang memberikan perhatian pada stimulus tersebut. Proses yang terjadi di dalamnya berlangsung setahap demi setahap (di poskan oleh Kartina Ningsih pada http://kartinaningsih.blogspot.com ).

Dari berbagai proses yang ada, terdapat satu proses sederhana yang sering terjadi dalam kehidupan kita sehari-hari namun tidak terlalu kita sadari. Proses tersebut adalah habituasi. Berikut ini akan dibahas mengenai apa itu habituasi dan bagaimana cara kita dapat mengenalinya dalam kehidupan sehari-hari.

Seperti yang dikemukakan oleh Budimansyah (2010:63) bahwa : 


\section{Jurnal Pendidikan Sosial Keberagaman}

Print-ISSN 2355-4622 Online-ISSN 2622-9021

Vol. 8, No. 1, Juli 2021, halaman 10-29

https://juridiksiam.unram.ac.id/index.php/juridiksiam

"Habituasi adalah proses penciptaan aneka situasi dan kondisi (persiste life situation) yang berisi aneka penguatan (reinforcement) yang memungkinkan peserta didik pada satuan pendidikannya, di rumahnya, di lingkungan masyarakatnya, membiasakan diri berperilaku sesuai nilai dan menjadikan perangkat nilai yang telah diinternalisasi dan dipersonalisasi melalui proses olah hati, olah pikir, olah raga, olah rasa dan olah karsa itu sebagai karakter atau watak."

Maka dari itu moral secara turun temurun diajarkan kepada generasi muda melalui penanaman kebiasaan (cultivation) yang menekankan pada mana benar dan salah secara absolut. Hal yang diajarkan kepada siswa didik adalah mengenalkan pada mereka nilai baik dan salah dan memberikan hukuman dan sanksi secara langsung maupun tak langsung manakala terjadi pelanggaran. Begitulah apa yang telah dilakukan oleh agama manapun dalam membentuk karakter umatnya, yaitu dengan janji pemberian hadiah atau pahala jika berbuat kebaikan dan pemberian siksa dan dosa jika berbuat kejahatan.

\section{B. Nilai-Nilai Karakter Masyarakat}

Kata karakter diambil dari bahasa Inggris character, yang juga berasal dari bahasa Yunani character. Awalnya, kata ini digunakan untuk menandai hal hal yang mengesankan dari koin (keping uang). Belakangan secara umum istilah character digunakan untuk mengartikan hal yang berbeda antara satu hal dengan yang lainnya, dan akhirnya juga digunakan untuk menyebut keamanan kualitas pada tiap orang yang membedakan dengan kualitas lainnya (Fatchul Mu'in, 2011:162).

Ada beberapa unsur dimensi manusia secara psikologis dan sosiologis yang menurut penulis layak untuk kita bahas dalam kaitannya dalam terbentuknya karakter pada manusia. Unsur-unsur ini kadang juga menunjukkan bagaimana karakter seseorang. Unsur-unsur tersebut antara lain sikap, emosi, kemauan, kepercayaan, dan kebiasaan.

\section{Perkembangan Budaya Lokal Masyarakat}

Ralph Linton mendefinisikan kebudayaan dinamakan struktur normative atau designs for living atau garis-garis atau petunjuk hidup (Ranjabar, 2006: 24). Sedangkan menurut D'Andrade dalam Supardan (2008: 201) pengertian kebudayaan mengacu pada kumpulan pengetahuan yang secara sosial diwariskan dari satu generasi ke generasi berikutnya yang kontras dengan makna sehari-hari yang hanya merujuk pada warisan sosial tertentu yakni tradisi sopan santun dan kesenian.

Kita dapat mengambil contoh salah satu suku atau komunitas adat yang ada di Sulawesi Selatan yaitu Suku Adat Kajang yang memiliki kubudayaan yang sangat kuat dan dapat di 


\section{Jurnal Pendidikan Sosial Keberagaman}

Print-ISSN 2355-4622 Online-ISSN 2622-9021

Vol. 8, No. 1, Juli 2021, halaman 10-29

https://juridiksiam.unram.ac.id/index.php/juridiksiam

pertahankan samapi dengan saat ini. Masayarakat Suku Kajang sangat mematuhi aturanaturan dalam kebudayaannya karena hukuman atau sangsi yang di jatuhi kepada sang pelanggar aturan itu sangatlah berat menurut keyakinan komunitas mereka. Hal inilah dapat di jadikan cerminan oleh masyarkat luar untuk tidak melakukan pelanggaran-pelanggaran yang bisa merugikan orang lain yang berada di sekitar kita.

\section{Peran Perilaku Anti Korupsi Dalam Masyarakat}

Hukum menetapkan apa yang harus dilakukan dan atau apa yang boleh dilakukan serta yang dilarang. Sasaran hukum yang hendak dituju bukan saja orang yang nyata-nyata berbuat melawan hukum, melainkan juga perbuatan hukum yang mungkin akan terjadi, dan kepada alat perlengkapan negara untuk bertindak menurut hukum. Sistem bekerjanya hukum yang demikian itu merupakan salah satu bentuk penegakan hukum. Menurut Dossy Iskandar Prasetyo dan Bernard L. Tanya mengemukakan bahwa etika memiliki peran sangat sentral bagi peradilan pidana yang masuiawi (Dossy \& Bernard, 2011 :15).

Korupsi di negara Indonesia sudah dalam tingkat kejahatan korupsi politik. Kondisi Indinesia yang terserang kanker politik dan ekonomi sudah dalam stadium kritis. Penyakit korupsi terus menggerogoti saraf vital dalam tubuh negara Indonesia, sehingga terjadi krisis institusional. Korupsi politik dilakuan oleh orang atau institusi yang memiliki kekuasaan politik, atau oleh konglomerat yang melakukan hubungan transaksional kolutif dengan pemegang kekuasaan. Dengan demikian, praktik kejahatan luar biasa berupa kejahatan ini berlangsung secara sistematis. (Hartanti, 2009: 3)

Keberhasilan KPK dalam mengungkap berbagai kasus korupsi di Indonesia menimbulkan beberapa pertanyaan. Apakah korupsi di Indonesia akan tuntas atau apa yang telah dilakukan oleh KPK merupakan suatu permulaan dari sebuah upaya yang sudah cukup menelan biaya banyak dalam memberantas korupsi ?. Pernyataan berbagai lembaga survey korupsi baik yang berkapasitas Internasional ataupun nasional tentang buruknya korupsi di Indonesia dan mencuatnya berbagai pemberitaan di media masa kemudian dengan adanya tuntutan keseriusan pemberantasan korupsi di daerah-daerah yang dilakukan oleh masyarakat, hal itu semua mengindikasikan adanya suatu "fenomena gunung es" terhadap masalah korupsi di Indonesia.

Selain dari pada kontrol yang dilakukan oleh berbagai pihak di atas, hal yang sangat perlu juga di perhatikan yaitu kesadaran diri masyarakat. Peran masyarakat untuk berperilaku 


\section{Jurnal Pendidikan Sosial Keberagaman}

Print-ISSN 2355-4622 Online-ISSN 2622-9021

Vol. 8, No. 1, Juli 2021, halaman 10-29

https://juridiksiam.unram.ac.id/index.php/juridiksiam

dalam kehidupannya sangat mempengaruhi keadaan lingkungan masyarakat yang ada di sekitar kita untuk berperilaku yang baik dan jujur. Menurut Hotma P. Sipubea (2010:5)

"Meskipun dalam negara sipil ini ia keluar dari keuntungan yang didapatkan dari kondisi alamiahnya, pada gilirannya ia akan mendapatkan keuntungan yang lebih besar. Kemampuan-kemampuan yang dimilikinya akan dirangsang dan berkembang, gagasan-gagasannya di perluas, perasaan-perasaannya menjadi lebih mulia, dan seluruh jiwanya terangkat. Dengan demikian, kondisi baru ini tidak akan mendegradasikan dirinya ketingkat yang lebih rendah daripada kondisi alamiah yang telah ia tinggalkan, ia justru diikat dengan berkah berkesinambungan dalam sebuahmomen membahagiakan yang akan ia rasakan selamanya. Selain itu, statusnya sebagai hewan bodoh tidak imaginatif (ditinggalkan), ia menjadi makhluk intelek, yakni seorang manusia."

Apa yang diungkapkan di atas sangat mencerminkan masyarakat tradisional kita dahulu.

Kita ketahui bersama bahwa bangsa Indonesia memiliki kekayaan suku dan budaya yang sangat banyak. Dengan berlimpahnya budaya yang di miliki bangsa ini dapat di jadikan sebagai landasan yang patut untuk di terapkan dalam masyarakat di era globalisasi modern saat ini yang sangat terbiasa dengan perbuatan konsumtif dan serba instan. Kebutuhan inilah yang menyebabkan keadaan masyarakat sangat terdesak untuk melakukan perbuatanperbuatan menyimpang yang di karenakan oleh kebutuhan yang memiliki nilai sangat tinggi saat ini. Selain itu, tingkat kepuasan masyarakat yang tidak ada batasnya sehingga menyebabkan kebutuhan itu selulu ingin di raih. Hal inilah salah satu faktor yang mendorong terjadinya perbuatan korup pada masyarakat kita.

Dalam konteks kekiniaan, telah lazim bahwa tantangan penegakan hukum yang paling utama adalah menuntaskan pemberantasan Korupsi, Kolusi, dan Nepotisme (KKN). Hal ini bukanlah hal yang aneh karena dalam beberapa tahun terakhir, hasil berbagai survei dan penelitian menempatkan Indonesia sebagai negara dengan kualifikasi tertinggi dalam hal korupsi dan kronisme. Bahkan menurut Jimly :

“.... KKN juga telah merambah pada dunia peradilan dan secara langsung menggerogoti hukum itu sendiri jauh lebih luas dari pemberantasan korupsi. Artinya adalah pemikiran serta tindakan sebagai upaya pemberantasan korupsi tidaklah dapat melepaskan pemikiran dan tindakan menurut hukum sebagai aplikasi dari cita-cita bentukan negara hukum (Rechts staat atau The Rule of Law).” (Jimly, 2009 : 141)

Arti lainnya adalah membangun logika gerakan pemberantasan korupsi bukanlah sekedar membangunlogika dan perspektif hukum pidana, tetapi membangun logikayang jauh lebih luas yakni persoalan sistem, struktur, kultur maupun kebijakan hukum itu sendiri. 


\section{Jurnal Pendidikan Sosial Keberagaman}

Print-ISSN 2355-4622 Online-ISSN 2622-9021

Vol. 8, No. 1, Juli 2021, halaman 10-29

https://juridiksiam.unram.ac.id/index.php/juridiksiam

Ketika sistem, struktur, kultur maupun kebijakan hukum belum mampu menopang tegaknya negara hukum, bukanlah hal aneh jika KKN menjadi makin parah.

Jika masyarakat telah memahami norma-norma dasar dalam konstitusi dan menerapkannya dalam kehidupan berbangsa dan bernegara, maka pasti mengetahui dan dapat mempertahankan hak-hak konstitusionalnya yang dijamin dalam UUD 1945. Selain itu, masyarakat dapat berpartisipasi secara penuh terhadap pelaksanaan UUD 1945 baik melalui pelaksanaan hak dan kewajibannya sebagai warga negara, berpatisipasi dalam penyelenggaraan negara dan pemerintahan, serta dapat pula melakukan kontrol terhadap penyelenggaraan negara dan jalannya pemerintahan. Kondisi tersebut dengan sendirinya akan mencegah terjadinya penyimpangan ataupun penyalahgunaan konstitusi.

\section{E. Kerangka Konsep}

Kearifan lokal (local wisdom) yang berupa nilai-nilai karakter dipegang teguh dan dipraktekkan dalam kehidupan sehari-hari pada masyarakat Kajang yang mendukung pembentukan perilaku anti korupsi, sudah saatnya digali dan aktualisasikan dalam membentuk perilaku anti korupsi warga masyarakat. Hal ini perlu dilakukan mengingat nilai-nilai karakter berupa kearifan lokal mampu menjadi pedoman hidup yang membimbing dan mengarahkan warganya ke arah tindakan atau perbuatan yang terpuji. Disamping itu nilai-nilai karakter ini telah hidup turun-temurun, dan diwariskan dari generasi sebelumnya ke generasi berikutnya untuk kemudian dibiasakan (habituasi) dalam tindakan nyata untuk tidak melakukan korupsi.

Perilaku anti korupsi bukanlah sesuatu yang diwariskan oleh generasi sebelumnya, maupun bukan sesuatu yang diterima begitu saja dari alam. Melainkan merupakan sesuatu yang dikonstruksi secara sosial melalui proses habituasi yang dilakukan dengan sengaja, dengan melibatkan berbagai media perantara pembentukan pembiasaan nilai-nilai karakter.

Terdapat bebeberapa media habituasi nilai-nilai karakter dalam membentuk perilaku anti korupsi, diantaranya adalah : keluarga, teman sebaya, lingkungan pendidikan, dan media (massa maupun elektronik), serta peraturan perundang-undangan yang berlaku. Dari media ini sesungguhnya seseorang melakukan internalisasi guna membentuk perilaku anti korupsi.

Meskipun sejak tahun 1999 pemerintah telah memberlakukan Undang-Undang Nomor 3 Tahun 1971 Jo Undang-Undang Nomor 31 Tahun 1999 tetang Pemberantasan Tindak Pidana Korupsi, ternyata dinilai belum cukup dapat membentuk perilaku anti korupsi bagi warga negara Indonesia. Ini berarti bahwa peraturan perundangan sebagai struktur sosial ternyata belum sepenuhnya sanggup membentuk perilaku anti korupsi. Olehnya itu habituasi 


\section{Jurnal Pendidikan Sosial Keberagaman}

Print-ISSN 2355-4622 Online-ISSN 2622-9021

Vol. 8, No. 1, Juli 2021, halaman 10-29

https://juridiksiam.unram.ac.id/index.php/juridiksiam

nilai-nilai karakter yang bersumber pada kearifan lokal dipandang penting untuk dijadikan pedoman dalam pembentukan karakter anti korupsi.

Masyarakat Kajang ditetapkan sebagai sasaran dalam penelitian ini mengingat bahwa komunitas Kajang sebagai salah bentuk masyarakat di propinsi Sulawesi Selatan yang masih memegang kuat tradisi dan budaya sebagai pedoman dalam bertingkah laku. Disamping itu pada masyarakat ini diduga masih terdapat beberapa nilai-nilai karakter yang diharapkan dapat membentuk perilaku anti korupsi, berikut dikemukakan kerangka konsepnya :

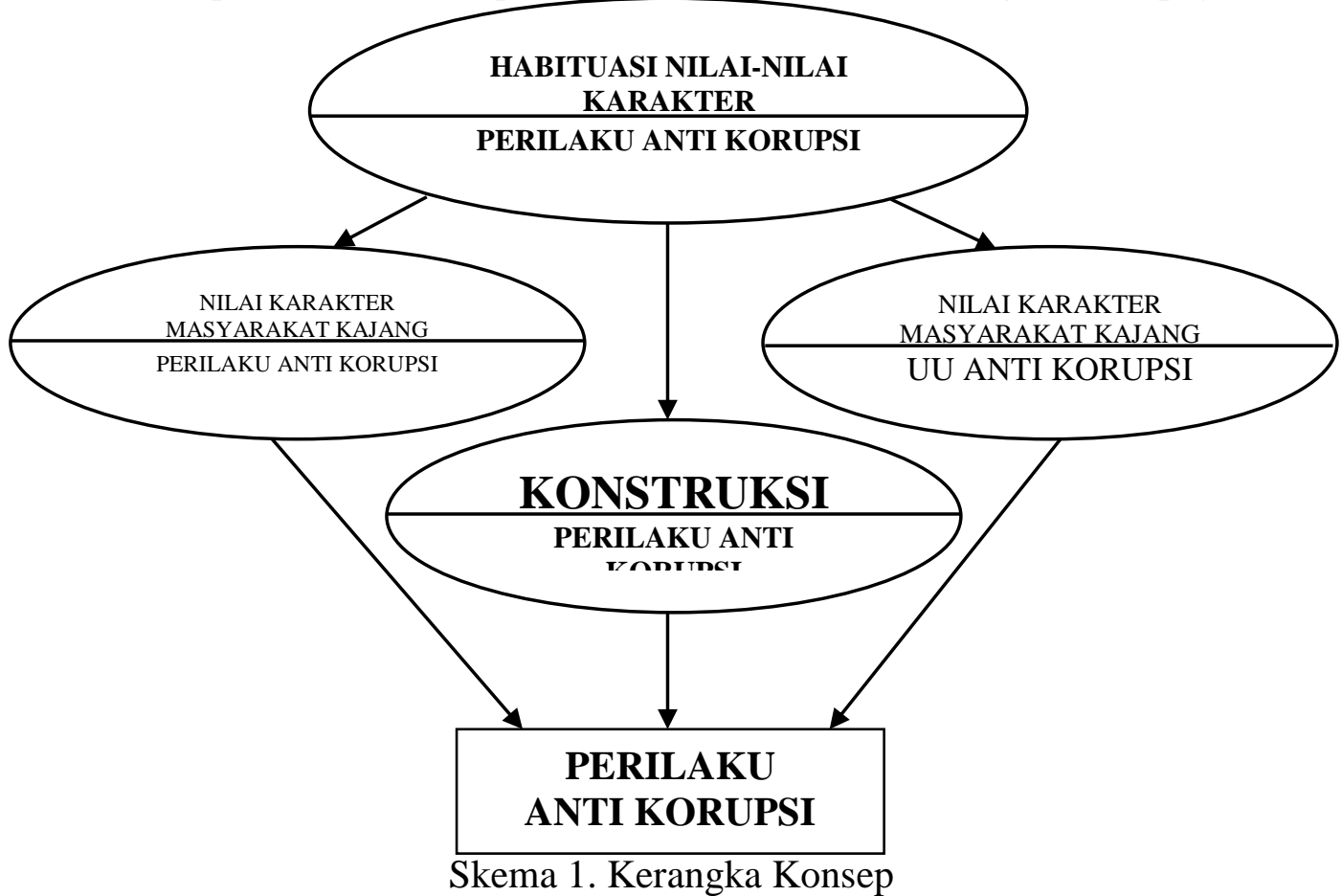

\section{Metode Kajian}

\section{A. Teknik Pengumpulan Data}

Teknik pengumpulan data yang akan dipergunakan dalam penelitian ini adalah :

1. Wawancara diarahkan kepada beberapa orang yang ditetapkan sebagai informan, mereka ini adalah orang yang dianggap paling tahu mengenai habituasi nilai-nilai karakter di masyarakat, baik yang mewakili pemimpin formal maupun non formal. Disamping itu wawancara mendalam juga diarahkan pada informan ahli, yakni pakar ilmu sosial yang menaruh minat yang besar pada masalah kearifan lokal (local wisdom) masyarakat Kajang, baik sosiolog, antropolog, sejarahwan. Dalam prakteknya wawancara dilengkapi dengan pedoman atau panduan wawancara. 


\section{Jurnal Pendidikan Sosial Keberagaman}

Print-ISSN 2355-4622 Online-ISSN 2622-9021

Vol. 8, No. 1, Juli 2021, halaman 10-29

https://juridiksiam.unram.ac.id/index.php/juridiksiam

2. Observasi (pengamatan) yang dilakukan dengan jalan pengamatan mengenai niali-nilai budaya Kajang, pencatatan secara sistematik terhadap gejala-gejala yang tampak pada objek penelitian sehingga data yang diperoleh dapat dipertanggungjawabkan.

3. Dokumentasi adalah Pengumpulan data dilakukan dengan mencari data yang berhubungan dengan fokus penelitian berupa catatan, traskrip, buku. Hal ini dilakukan guna mengetahui dengan tepat habituasi nilai-nilai karakter sebagai perilaku anti korupsi pada masyarakat Kajang, yang mencakup : nilai-nilai karakter yang dipegang kuat terkait dengan perilaku anti korupsi, dan nilai-nilai karakter (local wisdom) yang berkaitan erat dengan pendidikan anti korupsi.

\section{B. Fokus Penelitian}

Penelitian ini terfokus pada habituasi nilai-nilai karakter sebagai perilaku anti korupsi pada masyarakat Kajang, yang mencakup : nilai-nilai karakter yang dipegang kuat terkait dengan perilaku anti korupsi, nilai-nilai karakter (local wisdom) yang berkaitan erat dengan pendidikan anti korupsi, dan proses nilai-nilai karakter membentuk (mengkonstruksi) perilaku anti korupsi warga masyarakat.

\section{Metode Analisis Data}

Setelah data terkumpul, maka dilakukan kegiatan pengolahan data sesuai dengan jenis dan kebutuhan tujuan penelitian. Analisis deskriptif dilakukan dari awal sampai akhir. Peneliti melakukan analisis data dengan langkah-langkah analisis data kualitatif, mengikuti konsep yang diberikan oleh Miles, Huberman dan Spradley sebagaimana diuraikan Sugiono (2008:91)

1. Pengumpulan data (data collection); pada penelitian ini peneliti mengumpulkan data sambil memilah-milah dan memperdalam pencarian data yang telah fokus. Juga sudah mulai mengambil data dokumentasi.

2. Reduksi data (data reduction); memilih hal-hal yang pokok, memfokuskan hal-hal yang penting, dicari tema dan polanya. Data yang terkumpul peneliti kelompok-kelompokkan berdasarkan jenis kegiatan dan pokok masalahnya sesuai fokus penelitian.

3. Menyajikan data (data display); pada tahap ini, data yang terkumpul tentang habituasi nilai-nilai karakter sebagai perilaku anti korupsi pada masyarakat Kajang, yang mencakup : nilai-nilai karakter yang dipegang kuat terkait dengan perilaku anti korupsi, nilai-nilai karakter (local wisdom) yang berkaitan erat dengan pendidikan anti korupsi, 


\section{Jurnal Pendidikan Sosial Keberagaman}

Print-ISSN 2355-4622 Online-ISSN 2622-9021

Vol. 8, No. 1, Juli 2021, halaman 10-29

https://juridiksiam.unram.ac.id/index.php/juridiksiam

dan proses nilai-nilai karakter membentuk (mengkonstruksi) perilaku anti korupsi warga masyarakat.

4. Penarikan kesimpulan dan verifikasi (conclusion drawing and verification); kesimpulan yang dibuat dilakukan verifikasi ulang ke lapangan untuk mengetahui konsistensi data yang diperoleh pada saat penarikan kesimpulan awal.

\section{Pembahasan dan Kesimpulan}

\section{A. Pembahasan}

\section{Nilai-nilai Karakter (Local Wisdom) Masyarakat Kajang Yang Berkaitan Dengan Perilaku Anti Korupsi}

Budaya lokal memiliki peran yang sangat besar dalam membentuk pola perilaku masyarakat. Senada yang di ungkapkan oleh Ketua KPK Abraham Samad pada wawancara pada acara Televisi Hitam Putih Trans7 Pada tanggal 20 Mei 2013, yang menyatakan bahwa :

“... ada beberapa upaya untuk membangun Perilaku Anti Korupsi pada masyarakat oleh KPK, diantaranya melakukan sosialisasi-sosialisasi kepada masyarakat dalam pertemuanpertemuan atau penyuluhan tentang terjadinya korupsi, seminar serta yang di kembangkan saat ini tentang budaya lokal masyarakat di Negara kita yang memiliki beraneka ragam kultur, budaya merupakan garda awal atau dasar bagi masyarakat di Indonesia. Pelestarian budaya dalam karakter setiap warga masyarakat di Negara kita akan sangat mempengaruhi perlakuan tindak pidana korupsi kedepan, karena unsur-unsur dalam budaya dapat membentuk suatu tatanan masyarakat yang baik terlbih dalam persoalan korupsi...”.

(Sumber : Wawancara tanggal 20 Mei 2013 pada Acara Hitam Putih Trans7)

Budaya dan karakter merupakan satu kesatuan yang sangat erat kaitannya satu sama lainnya. Karakter yang ada di dalam diri seseorang tidak lain di pengaruhi oleh nilai-nilai budaya yang hidup di daerahnya. Selain itu, lingkungan keluarga merupakan awal pada karakter yang terbentuk dalam setiap masyrakat. Menurut Suyatno, setidaknya terdapat sembilan pilar karakter yang berasal dari nilai-nilai luhur universal sebagai berikut :

a) Cinta Tuhan dan segenap ciptaan-Nya ;

b) Kemandrian dan tanggung jawab ;

c) Kejujuran/amanah ;

d) Hormat dan santun ;

e) Dermawan, suka menolong, dan kerja sama ;

f) Percaya diri dan pekerja keras ;

g) Kepemimpinan dan keadilan ;

h) Baik dan rendah hati ;

i) Toleransi, kedamaian dan kesatuan. (Azzet, $2011: 29$ )

Kesembilan pilar karakter sebagaimana di atas hendaknya diajarkan secara sistematis dalam model pendidikan yang holistik. Apabila kesembilan pilar karakter tersebut benar- 


\section{Jurnal Pendidikan Sosial Keberagaman}

Print-ISSN 2355-4622 Online-ISSN 2622-9021

Vol. 8, No. 1, Juli 2021, halaman 10-29

https://juridiksiam.unram.ac.id/index.php/juridiksiam

benar dipahami, dirasakan kebaikan dan perlunya dalam kehidupan, serta diwujudkan dalam perilaku sehari-hari, inilah sesungguhnya karakter yang di harapkan terdapat dalam diri setiap warga negara. Karakter merupakan sebuah sifat dan perilaku yang melekat dalam diri seseorang guna menjalankan kehidupan sehari-hari. Karakter masyarakat Kajang merupakan hasil manifestasi dari Pasang yang di wariskan oleh nenek moyang mereka untuk di jalankan sesuai amanat dari isi Pasang itu sendiri.

Komunitas Ammatoa bersama seluruh nilai dan sistem budayanya, melahirkan dan menampilkan fenomena sosial tersendiri. Mereka cenderung membatasi diri dari semua aktivitas yang mengutamakan keduniaan. Sikap dan perilaku seperti ini di jalankan oleh masyarakat adat Kajang bukan berarti mereka tertutup dengan dunia luar, tetapi mereka lebih mengedepankan sikap untuk berhati-hati dan lebih selektif dalam menjaga tatanan kehidupan mereka dengan melaui prinsip kamase-asea. Dalam kehidupan masyarakat adat Kajang, mereka dituntun untuk melakukan perilaku sosial yang baik yang tertuang dalam Pasang. Ketika terjadi suatu perilaku yang menyimpang oleh komunitas masyarakat adat Kajang, akan di jatuhi sanksi sesuai yang di amanatkan dalam Pasang. Selaku pimpinan adat peran Ammatoa disini sebagai wakil dari Tau Rie' A'rakna atau Tuhan Yang Maha Esa untuk menjadi pelindung bagi masyarakat adat Kajang secara utuh.

Ketika ada orang di dalam komunitasnya melakukan pelanggaran yang melanggar dari Pasang, maka Ammatoa yang berhak untuk menjatuhkan sanksi melalui sidang adat kepada orang tersebut. Namun, ketika orang yang melanggar tersebut tetap tidak mengakui kesalahannya maka dia akan diberikan sanksi yang paling berat, yaitu di asingkan dari kehidupan adat masyarakat Kajang atau di usir dari daerah adat Kajang dan tidak berguna lagi bagi masyarakat Kajang. Pasang sangat tidak menganjurkan kepada kita untuk berperilaku yang buruk, isi dari pada Pasang merupakan kandungan nilai majemuk yang mengatur dan menata kehidupan perilaku sosial masyarakat secara utuh. Diungkapkan oleh Bohe Amma bahwa seseorang dalam adat tidak boleh melakukan tindakan korupsi (soso'), ketika dilakukan akan mendapatkan sanksi yang telah ditentukan oleh Pasang.

Perbuatan tindak pidana korupsi merupakan suatu hal yang sangat meresahkan di negara kita. Dapat dikatakan tindakan perilaku korupsi di negara indonesia saat ini di serang oleh penyakit kanker yang sangat ganas. Hal ini, disebabkan oleh kurangnya kesadaran diri dalam masyarakat untuk berperilaku baik dan tidak menyimpang dari norma-norma sosial. Orang yang kaya pada saat ini terkadang dipandang oleh masyarakat awam sebagai orang yang 


\section{Jurnal Pendidikan Sosial Keberagaman}

Print-ISSN 2355-4622 Online-ISSN 2622-9021

Vol. 8, No. 1, Juli 2021, halaman 10-29

https://juridiksiam.unram.ac.id/index.php/juridiksiam

melakukan korupsi. Namaun, hal ini tidaklah dapat langsung dibenarkan tanpa memiliki bukti yang jelas. Tidak dapat dipungkiri bahwa banyak juga oang yang kaya dengan hasil dari keringat mereka sendiri tanpa melakukan kecurangan. Peranan budaya atau nilai-nilai karakter (Local Wisdom) suatu budaya sangat di butuhkan untuk mencegah perilaku korupsi akan terjadi kedepannya. Nilai karakter masyarakat adat Kajang yang berkaitan dengan Perilaku Anti Korupsi dapat dideskripsikan bahwa Pasang merupakan suatu tatanan yang majemuk diwariskan oleh leluhur dari masyarakat adat Kajang untuk dijadikan sebagai tuntunan dalam menjalankan kehidupan di dunia yang tidak terlepas dari prinsip hidup kamase-asea atau dengan kesederhanaan tanpa mengejar kekayaan secara berlebihan.

\section{Kesesuaian Antara Nilai-Nilai Karakter Komunitas Masyarakat Kajang Dengan}

\section{Undang-Undang Anti Korupsi}

Pasang Ri Kajang dilihat dari segi isi dan makna yang dipesankan mengandung beberapa pengertian. Pasang dapat berarti nasehat atau wasiat dapat pula berarti tuntunan atau amanah dan juga dapat bermakna renungan atau ramalan. Selain itu dapat pula berarti peringatan atau mengingat. Begitulah antara lain pengertian-pengertian tentang Pasang Ri Kajang. Selanjutnya, isi dan doktrin yang terkandung dalam Pasang, baik berupa wasiat, peringatan maupun yang merupakan amanah dan tuntunan, semuanya itu merupakan nilai budaya dan nilai sosial oleh masyarakat pemiliknya yaitu masyarakat Amma Towa. Doktrin atau materimateri Pasang yang menghendaki adanya suatu kegiatan sebagai umpan balik dari doktrin tersebut pelaksanaannya langsung diawasi oleh Amma Towa sebagai pemimpin adat. Dan pelaksanaan itu sendiri menjadi suatu tradisi yang melembaga dalam berbagai institusiinstitusi dan lembaga-lembaga sosial. Komudian dari seluruh gerak kelembagaan tersebut baik yang dilaksanakan secara pribadi maupun secara berkelompok akhirnya disampaikan pula kepada generasi berikutnya, dan penyampaian itu merupakan materi dari Pasang. Sehingga wujud Pasang itu sebenarnya merupakan himpunan dari seluruh pengetahuan dan pengalaman di masa lampau yang mencakup semua aspek kehidupan nenek moyang dan leluhur masyarakat Amma Towa. Dengan demikian materi-materi Pasang itu bukan hanya verbal tetapi juga yang aktual. Artinya meliputi perbuatan dan tingkah laku.

Komunitas Ammatowa bersama seluruh nilai dan sistem budayanya, melahirkan dan menampilkan nuansa atau fenomena sosial tersendiri. Mereka cenderung membatasi diri dari semua aktivitas yang mengutamakan keduniaan. Sikap dan perilaku seperti ini bukan berarti mereka tertutup dengan lingkungan luar, tapi lebih mengedepankan sikap berhati-hati dan 


\section{Jurnal Pendidikan Sosial Keberagaman}

Print-ISSN 2355-4622 Online-ISSN 2622-9021

Vol. 8, No. 1, Juli 2021, halaman 10-29

https://juridiksiam.unram.ac.id/index.php/juridiksiam

selektif dalam menjaga tatanan kehidupan mereka dengan prinsip Kamase-masea (kesederhanaan hidup) sesuai yang tertuang dalam Pasang. Sebagaimana yang di ungkapkan dalam wawancara pada tanggal 25 Juli 2013 oleh Bohe Amma (sapaan buat Ammatowa), bahwa :

“Ammentengko пи kamase-mase, A'cci'dongko nu kamase-mase, A'dakkako nu kamasemase, A'meako nu kamase-mase".

Artinya:

"Berdiri engkau sederhana, duduk engkau sederhana, berjalan engkau sederhana, berbicara engkau sederhana".

(Sumber : Hasil wawancara pada tanggal 25 Juli 2013)

Dan juga dalam Pasang :

“Anre kalumannyang kalupepeang, Rie' kamase-masea, Angnganre na rie', Care-care narie', Pammalli juku' na rie', Koko na rie', Balla situju-tuju. Artinya:

"Kekayaan itu tidak kekal, yang ada hanya kesederhanaan, Makan secukupnya, pakaian secukupnya, pembeli ikan secukupnya, kebun secukupnya, rumah seadanya".

(Sumber: Hasil wawancara pada tanggal 25 Juli 2013)

Tallasa' kamase-masea ini merupakan prinsip hidup masyarakat adat Kajang. Tallasa Kamase-masea dipegang teguh oleh masyarakat, meskipun secara sadar mereka mengetahui bahwa hidup lebih sejahtera dapat mereka peroleh karena potensi sumber daya lingkungan (hutan) yang mendukung. Masyarakat adat Kajang menerapkan ketentuan-ketentuan adat dalam kehidupan sehari-hari termasuk dalam pemanfaatan hutan. Ketentuan adat yang diberlakukan di wilayah adat Ammatoa Kajang diberlakukan kepada seluruh komponen masyarakat tanpa kecuali. Ketentuan ini berlandaskan pesan leluhur yang disampaikan secara turun temurun. Ketentuan adat ini dipandang sebagai sesuatu yang baku (lebba) yang diterapkan kepada setiap orang yang telah melakukan pelanggaran yang dapat merusak kelestarian lingkungan hutan. Dalam hal ini diberlakukan sikap tegas (gattang), dalam arti konsekuen dengan aturan dan pelaksanaannya tanpa ada dispensasi, sebagaimana disebutkan dalampasang yang berbunyi: 'Anre na'kulle nipinra-pinra punna anu lebba' Artinya : Jika sudah menjadi ketentuan, tidak bisa dirubah lagi (Restu dan Sinohadji, 2008).

Dalam Makalah Mansjur Embas (seorang Budayawan dan pada saat ini menjabat sebagai Ketua Aliansi Masyarakat Adat Nusantara (AMAN) Kabupaten Bulukumba) yang berjudul "Kearifan Lokal Masyarakat Adat Amma Toa Kecamatan Kajang Dalam Memelihara dan Mengelola Sumber Daya Alam" dikemukakan bahwa berat atau ringannya 


\section{Jurnal Pendidikan Sosial Keberagaman}

Print-ISSN 2355-4622 Online-ISSN 2622-9021

Vol. 8, No. 1, Juli 2021, halaman 10-29

https://juridiksiam.unram.ac.id/index.php/juridiksiam

sanksi yang diberikan kepada pelaku ditetapkan sesuai tingkat pelanggaran yang dilakukan, sanksi adat yang berlaku di Tanah Toa adalah :

a) Pokok Babbala (Pelanggaran Berat);

b) Tangnga Babbala (Pelanggaran Sedang); dan

c) Cappa Babbala (Pelanggaran Ringan).

Ketiga tatanan pelanggaran di atas memiliki sanksi yang sangat tegas dan dipercayai oleh masyarakat adat Kajang bahwa ketika ketentuan yang tersebut di atas tidak di indahkan maka orang yang melanggar tersebut akan terasingkat oleh masyarakat adat serta akan mendapatkan mala petaka dalam kehidupannya dari Tu Riek A'rakna atau Tuhan Yang Maha Esa. Jika, sanksi dari masyarakat adat seperti yang dikemukakan di atas sangat ditakuti oleh masyarakat untuk melanggar ketentuaan yang telah tertuang dalam Pasang, berbeda halnya dengan dengan Undang-Undang Tindak Pidana Korupsi yang memberikan celah kepada terpidana untuk tidak mengembalikan hasil korupsi yang telah di ambil dan dapat membentuk suatu perilaku ketidak jeraan untuk melakukan tindakan korupsi. Dapat juga dilihat dalam pelaksanaan hukum positif yang berlaku di negara kita. Mengadili menurut hukum dan tidak membeda-bedakan orang karena alasan ras, suku, agama maupun latar belakang bukan hanya berlaku dalam pengadilan saja tetapi maknanya juga dalam pelaksanan penegakan hukum oleh aparat penegak hukum yang lain untuk melaksanakan sesuai ketentuan hukum yang berlaku dan tidak membeda-bedakan orang. Adanya penyimpangan terhadap asas tidak membeda-bedakan orang hanya dapat diterima dengan alasan sangat sempit yaitu bilamana senyatanya penyimpangan tersebut demi keadilan dan manfaat bagi mereka yang dibedakan.

Peran penegak hukum harus dapat menjamin keseimbangan antara rasa keadilan, kegunaan atau kemanfaatan dan kepastian hukum dalam pelaksanaan penegakan hukum untuk menemukan kepuasan bagi mereka yang mendabakan keadilan. Penegak hukum hendaknya berpedoman keadilan yang bermanfaat atau memberi kemanfaatan dan berkepastian hukum serta kemanfaatan yang berkeadilan. Jelas tertuang bahwa aturan yang diberlakukan oleh pemerintah dalam hal ini hukum positif berupa Undang-Undang Anti Korupsi juga diterapkan oleh komunitas adat Ammatoa. Meskipun, ada beberapa perbedaan dalam bentuknya dan penerapannya. 


\section{Jurnal Pendidikan Sosial Keberagaman}

Print-ISSN 2355-4622 Online-ISSN 2622-9021

Vol. 8, No. 1, Juli 2021, halaman 10-29

https://juridiksiam.unram.ac.id/index.php/juridiksiam

Secara konsep nilai komunitas adat Kajang melalui prinsip kamase-asea dalam Pasang membentuk perilaku Anti Korupsi, dapat dideskripsikan sebagai berikut :

\begin{tabular}{|c|c|c|}
\hline $\begin{array}{c}\text { Local Wisdom } \\
\text { (Fakta Sosial) }\end{array}$ & $\begin{array}{c}\text { Anti Korupsi } \\
\text { (Fakta Hukum) }\end{array}$ & Jalur Konstruksi \\
\hline Kamase-asea & $\begin{array}{l}\text { UU Nomor } 20 \text { Tahun } 2001 \text { Tentang } \\
\text { Perubahan Atas UU Nomor } 31 \\
\text { Tahun } 1999 \text { Tentang Pemberantasan } \\
\text { Tindak Pidana Korupsi }\end{array}$ & $\begin{array}{l}>\text { Lingkungan Keluarga } \\
>\text { Lingkungan Masyarakat }\end{array}$ \\
\hline
\end{tabular}

Dari gambaran pada tabel di atas, dapat dideskripsikan bahwa proses internalisasi fakta sosial yang terjadi melalui prinsip kamase-asea sebagai nilai yang di pegang teguh oleh masyarakat adat Kajang dengan Perilaku Anti Korupsi sebagai fakta hukum yang tertuang dalam Undang-Undang Nomor 20 Tahun 2001 Tentang Perubahan atas Undang-Undang Nomor 31 Tahun 1999 Tentang Pemberantasan Tindak Pidana Korupsi yang terjadi melalui jalur Lingkungan Keluarga serta Lingkungan Masyarakat. Selain itu, sanksi yang tegas dan berat diperlukan sehingga masyarakat tidak berani untuk melakukan pelanggaran. Hal inilah yang dapat membentuk suatu sikap Perilaku Anti Korupsi dalam masyarakat secara umum.

\section{Nilai-Nilai Karakter Komunitas Kajang Membentuk (Mengkonstruksi) Perilaku}

\section{Anti Korupsi Warga Masyarakat}

Nilai-nilai sosial merupakan tingkah laku dan perbuatan manusia yang dapat dinilai sebagai perbuatan yang bernilai baik dan buruk. Dengan demikian nilai sosial dalam Pasang adalah petunjuk-petunjuk dan penggarisan Pasang tentang suatu perbuatan yang bernilai baik ataupun buruk. Bertolak dari kerangka teori di atas, maka nilai sosial dalam Pasang dapat berwujud norma-norma atau adat istiadat, perihal yang dianggap sirik, dan pantanganpantangan.

\section{Norma atau adat istiadat}

Norma-norma dan adat istiadat pada uraian ini lebih dititik beratkan pada pandangan atau sikap yang abstrak yang merupakan perwujudan dari sistem nilai budaya. Dalam hubungannya dengan Pasang dapat dirumuskan ke dalam empat kerangka yaitu :

- Jujur, Nilai sosial yang paling utama dan paling mendasar yang digariskan dalam ajaran Pasang adalah kejujuran. Nilai kejujuran ini diungkapkan dengan kalimat "Lambusuk-nuji nukaraeng” yang artinya karena kejujuranmu maka engkau menjadi penguasa. Betapa tinggi nilai kejujuran itu dapat dilihat dalam pengungkapan secara filosofis dengan katakata kiasan “Accidong Ri Tanah Eso”. Ungkapan ini berarti bahwa duduk di tanah lapang. Mereka tidak khawatir menghadapi tantangan disebabkan karena kejujurannya. Ini 


\section{Jurnal Pendidikan Sosial Keberagaman}

Print-ISSN 2355-4622 Online-ISSN 2622-9021

Vol. 8, No. 1, Juli 2021, halaman 10-29

https://juridiksiam.unram.ac.id/index.php/juridiksiam

diperkuat lagi dengan ungkapan lainnya yaitu "Akkambiang ri cinaguri". Ungkapan ini bermakna orang yang jujur mendapat perlindungan dari Yang Maha Kuasa. Sebab kejujuran itu termasuk nilai sosial yang terpuji, jadi orang yang memiliki dan memeliharanya juga temasuk orang yang dilindungi. Cinaguri sebenarnya adalah jenis tumbuhan yang sangat sederhana, kecil namun diibaratkan sebagai pohon yang dapat dijadikan tempat berlindung atau tempat bernaung.

- Sabar, Sabar (sabbara) atau tabah merupakan nilai sosial yang harus dimiliki oleh setiap pengikut ajaran Pasang, terutama bagi mereka yang mempunyai tugas sebagai pendidik, atau mereka yang mengetahui tata aturan dan adat istiadat. Sebagaimana diungkapkan dalam Pasang "Sabbarak-nuji nu guru", yang berarti lantaran kesabaranmu maka engkau menjadi guru atau pendidik. Maksudnya seorang pendidik harus memiliki sifat tabah dan sabar, sebab mendidik itu membutuhkan keuletan dan kesabaran.

- Konsekuen, Konsekuen merupakan nilai sosial yang menempati posisi yang paling penting dalam kehidupan sosial masyarakat Amma Towa. Sifat tersebut diungkapkan dengan kalimat "Ri Gattanuji nu adak", yang artinya lantaran ketegasanmu maka engkau menjadi pemimpin adat. Nilai sosial yang konsekuen begitu penting dimiliki sebab seorang pemimipin adat yang tidak tegas, maka adat istiadat akan mudah dan gampang untuk ditinggalkan. Konsekuen disini menghendaki pula suatu sikap tunduk dan patuh terhadap peraturan. Termasuk konsekuen terhadap suatu keputusan. Ini terlihat dalam ungkapan "Sallu Ri Ajoa", yang berarti tunduk pada gagang bajak. Dan ungkapan "Ammulu Ri Adahang". Dua ungkapan ini bermakna betapa pentingnya seseorang konsekuen terhadap tata aturan dan adat istiadat.Sallu Ri Ajoka bermakna bahwa setiap orang harus tunduk dan patuh terhadap norma-norma yang telah digariskan dalam Pasang.edangkan ungkapan "Ammulu Ri Adahang”, yang berarti bertolak dari jalur bajakan, bermakna bahwa dalam suatu pekerjaan hendaklah konsekuen terhadap program atau ketentuan-ketentuan yang telah disepakati.

- Tenggang Rasa, Nilai sosial berupa tenggang rasa sangat diutamakan oleh para dukun. Seperti diungkapkan dalam Pasang "Pesona nuji nisanro", yang bisa berarti bahwa lantaran engkau tenggang rasa atau pasrah maka engkau menjadi dukun. Sifat ini diutamakan kepada para dukun sebab pekerjaan dukun memerlukan sifat tenggang rasa atau sifat lapang dada. Dan sifat seperti ini merupakan nilai sosial yang sama nilainya 


\section{Jurnal Pendidikan Sosial Keberagaman}

Print-ISSN 2355-4622 Online-ISSN 2622-9021

Vol. 8, No. 1, Juli 2021, halaman 10-29

https://juridiksiam.unram.ac.id/index.php/juridiksiam

dengan sifat-sifat yang disebutka sebelumnya. Artinya, menurut standar penilaian Pasang,

sifat tenggang rasa atau pasrah itu mempunyai nilai positif dan berharga.

Abu Ayyub Thalib sebagai Kepala Desa Tambangang yang dalam struktur adat merupakan Karaeng Tallua (Anak Karaeng Tambangang Moncong Buloa) mengemukakan bahwa :

“... sebagai makhluk sosial, yang hidup berdampingan dengan berbagai sifat, sikap dan perilaku masyarakat yang ada di sekitar kita, harus saling menghormati dan menghargai dalam berperilaku dengan orang-orang yang berada disekitar kita. Terlebih kami yang merupakan komunitas masyarakat Kajang yang masih memegang teguh warisan leluhur melalui Pasang yang di wariskan kepada kami ..."

(Sumber : Hasil wawancara pada tanggal 26 Juli 2013)

Selanjutnya, di tambahkan bahwa :

“... alangkah baiknya kehidupan sosial yang kita terapkan dengan meniru konsep filosofis dari padi, dimana semakin dia berisi maka semakin menunduk, hal ini menggambarkan kita bahwa hidup dengan kesederhanaan itu lebih baik dibandingkan kita hidup dengan serba berkelebihan...".

(Sumber : Hasil wawancara pada tanggal 26 Juli 2013)

Nilai-nilai sosial merupakan tingkah laku dan perbuatan manusia yang dapat dinilai sebagai perbuatan yang bernilai baik dan buruk. Dengan demikian nilai sosial dalam Pasang adalah petunjuk-petunjuk dan penggarisan Pasang tentang suatu perbuatan yang bernilai baik ataupun buruk. Niai-nilai kehidupan diatas merupakan suatu perilaku yang dalam penerapannya dilakukan dalam kehidupan sehari-hari. Sifat-sifat dan perilaku tersebut kiranya dapat dibangun dalam lingkungan keluarga dan lingkungan masyarakat, sebagaimana yang di ungkapkan oleh Akhmad Muhaimin Azzet dalam bukunya "Urgensi Pendidikan Karakter Di Indonesia", bahwa :

“... Banyak penelitian membuktikan bahwa pada usia kanak-kanak sangat menentukan kemampuan dapat mengembangkan potensi yang dimilikinya secara optimal. Hasil penelitian tersebut menyebutkan bahwa sekitar 50\% variabilitas kecerdasan orang dewasa sudah terjadi ketika anak berusia empat tahun. Dengan memperhatikan hasil penelitian ini, disamping pendidikan sekolah yang berkewajiban dalam membangun karakter yang baik pada diri anak didik, orang tua juga sama sekali tidak boleh melepaskan begitu saja pendidikan kepada sekolah. Orang tua justru mempunyai kewajiban yang utam dalam hal ini. Betapa penting masa kanak-kanak tersebut untuk membangun pilar karakter yang baik bagi anak. Setelah pada masa usia keemasan sebagaimana di atas, peningkatan $30 \%$ berikutnya terjadi pada usia delapan tahun, sedangkan yang $20 \%$ sisanya pada pertengahan atau akhir dasawarsa kedua ...”. (Azzet, 2011; 34 - 35)

Dari gambaran di atas, dapat dideskripsikan bahwa proses internalisasi fakta sosial yang terjadi melalui prinsip kamase-asea sebagai nilai yang di pegang teguh oleh masyarakat adat 


\section{Jurnal Pendidikan Sosial Keberagaman}

Print-ISSN 2355-4622 Online-ISSN 2622-9021

Vol. 8, No. 1, Juli 2021, halaman 10-29

https://juridiksiam.unram.ac.id/index.php/juridiksiam

Kajang dengan Perilaku Anti Korupsi sebagai fakta hukum yang terjadi melalui jalur Lingkungan Keluarga serta Lingkungan Masyarakat. Selain itu, sanksi yang tegas dan berat diperlukan sehingga masyarakat tidak berani untuk melakukan pelanggaran. Hal inilah yang dapat membentuk suatu sikap Perilaku Anti Korupsi dalam masyarakat secara umum.

\section{B. Kesimpulan}

Berdasarkan uraian penelitian dan pembahasan, maka penulis menarik kesimpulan yang berkaitan dengan permasalahan yang diteliti sebagai berikut:

1. Nilai karakter masyarakat adat Kajang berkaitan dengan Perilaku Anti Korupsi dapat dideskripsikan bahwa Pasang atau pesan merupakan suatu tatanan yang majemuk diwariskan oleh leluhur dari masyarakat adat Kajang untuk dijadikan sebagai tuntunan dalam menjalankan kehidupan di dunia yang tidak terlepas dari prinsip hidup kamaseasea.

2. Pemberlakuan Undang-Undang Anti Korupsi oleh pemerintah juga diterapkan oleh komunitas adat Ammatoa. Meskipun, ada perbedaan karena aturan-aturan yang diberlakukan oleh komunitas adat Ammatoa tidak tertulis, melainkan berupa Pasang atau pesan yang sangat dipatuhi oleh masyarakat adat Kajang.

3. Proses internalisasi fakta sosial yang terjadi melalui prinsip kamase-asea sebagai nilai yang di pegang teguh oleh masyarakat adat Kajang dengan Perilaku Anti Korupsi sebagai fakta hukum yang terjadi melalui jalur Lingkungan Keluarga serta Lingkungan Masyarakat. Selain itu, sanksi yang tegas dan berat diperlukan sehingga masyarakat tidak berani untuk melakukan pelanggaran. Hal inilah yang dapat membentuk suatu sikap Perilaku Anti Korupsi dalam masyarakat secara umum.

\section{Implikasi dan Keterbatasan}

\section{A. Implikasi Temuan}

Temuan yang dapat disampaikan berkaitan penelitian ini adalah:

1. Dalam kehidupan masyarakat secara tidak langsung atau tanpa kita sadari perubahan budaya terus menerus terjadi dima 91 tur dari budaya kita saat ini lama kelamaan mulai memudar akibat pengaruh-pengaruh dari perkembangan zaman dan akan berpengaruh kepada nilai-nilai karakter yang terdapat dalam masyarakat di waktu yang akan datang.

2. Melestarikan dan mempertahankan budaya lokal yang ada merupakan aset yang sangat berharga bagi Negara Republik Indonesia yang beraneka ragam demi untuk memupuk adat istiadat atau kebiasaan-kebiasaan yang hidup dalam sendi-sendi kehidupan 


\section{Jurnal Pendidikan Sosial Keberagaman}

Print-ISSN 2355-4622 Online-ISSN 2622-9021

Vol. 8, No. 1, Juli 2021, halaman 10-29

https://juridiksiam.unram.ac.id/index.php/juridiksiam

masyarakat untuk tetap menjalankan adat isti adat tersebut demi terciptanya keselarasan nilai-nilai yang ada pada masyarakat.

3. Masyarakat hendaklah sadar akan perbuatan-perbuatan menyimpang yang telah dilakukan terlebih lagi pada persoalan korupsi karena tidak sesuai dengan budaya yang kita anut dan melanggar perundang-undangan yang telah diatur oleh pemerintah.

4. Lingkungan Keluarga merupakan dasar pembentukan nilai-nilai karakter, hendaklah menciptakan nilai-nilai yang positif kepada anggota keluarga agar dapat membenahi dan membantu Negara untuk menciptakan Budaya Prilaku Anti Korupsi secara utuh.

\section{B. Keterbatasan Kajian}

Keterbatasan kajian yang dapat disampaikan oleh peneliti bahwa kajian dalam penelitian ini hanya terbatas pada bagaimana mengaplikasikan nilai-nilai karakter yang ada dalam masyarakat adat untuk di aplikasikan ke dalam perilaku anti korupsi serta dalam ini juga peneliti mengkaji tentang keterkaitannya dengan aturan perundang-undangan yang berlaku untuk di aplikasikan kepada masyarakat secara umum dan dengan tujuan untuk mencegah dan mengantisipasi pelanggaran Tindak Pidana Korupsi yang marak terjadi di Negara kita saat ini.

\section{Daftar Pustaka}

\section{$\underline{\text { Buku }}$}

Akib, Yusuf. 2008. Ammatoa Komunitas Berbaju Hitam. Makassar : Pustaka Refleksi

Ali, Mahrus. 2011. Hukum Pidana Korupsi di Indonesia. Yogyakarta : UII Press

Asshiddiqie, Jimly. 2009. Menuju Negara Hukum Yang Demokratis. Jakarta : PT. Buana Ilmu Populer.

Azzet, Akhmad Muhaimin. 2011. Pendidikan Karakter, Konstruksi Teoritik dan Praktik. Jogjakarta : Ar-Ruzz Media.

Budimansyah, Dasim. 2010. Penguatan Pendidikan Kewarganegaraan Untuk Membangun Karakter Bangsa. Bandung : Widya Aksara Press.

Embas, Mansjur. 2010. Kearifan Lokal Masyarakat Adat Amma Toa Kecamatan Kajang Dalam Memelihara dan Mengelola Sumber Daya Alam. Makalah.

Hartanti, Evi. 2009. Tindak Pidana Korupsi : Edisi Kedua. Jakarta : Sinar Grafika.

Katu, Mas Alim. 2008. Kearifan Manusia Kajang. Makassar : Pustaka Refleksi.

Mu'in, Fatchul. 2011. Pendidikan Karakter, Konstruksi Teoritik dan Praktik. Jogjakarta : ArRuzz Media. 


\section{Jurnal Pendidikan Sosial Keberagaman}

Print-ISSN 2355-4622 Online-ISSN 2622-9021

Vol. 8, No. 1, Juli 2021, halaman 10-29

https://juridiksiam.unram.ac.id/index.php/juridiksiam

Prasetyo, Dossy Iskandar dan Tanya, Bernard L. 2011. Hukum, Etika, dan Kekuasaan. Yogyakarta : Genta Publishing.

Ranjabar, Jacobus. 2006. Sistem Sosial Budaya Indonesia. Bogor : Ghalia Indonesia.

Sibuea, Hotma P. 2010. Asas Negara Hukum, Peraturan Kebiajakan, dan Asas-Asas Umum Pemerintah Yang Baik. Jakarta : Erlangga.

Supardan, Dadang. 2008. Pengantar Ilmu Sosial Sebuah Kajian Pendekatan Structural. Jakarta : Bumi Aksara.

Sugiyono. 2008. Metode Penelitian Kuantitatif,Kualitatif, dan R\&D. Bandung : Alfabeta.

\section{Website}

http://nasional.kompas.com/read/2011/12/02/02374487/Indonesia.Masih.Negara.Terkorup

http://kartinaningsih.blogspot.com

\section{Perundang-Undangan}

Undang-Undang Nomor 31 Tahun 1999

Undang-Undang Nomor 20 Tahun 2001 